\title{
Ultrastructure on the Light Organ of Tropical Synchronize Firefly, Pteroptyx tener
} (Ultrastruktur Organ Cahaya pada Kelip-kelip Tropika Berkelip Sederap, Pteroptyx tener)

\section{NUR KHAIRUNNISA BINTI SALLEH, NURUL WAHIDA BINTI OTHMAN, NORELA BINTI SUlAIMAN* \& ISMAIL BIN SAHID}

\section{ABSTRACT}

The ultrastructure of the light organ Pteroptyx tener was examined using a Carl Zeiss Axioscope microscope and transmission electron microscope (TEM). The light organ of the male and female P. tener comprises of two layers namely the photogenic layer and the dorsal (reflector) layer. Photogenic layer consists of several elements, i.e. photocyte, differentiated zone, cylinder, trachea and trachea end cell. The photocyte is the main source of the emitted light. This layer is packed with photocyte granules except at a differentiated zone that have low granules but high number of mitochondria. The reflector layer comprised of trachea and the cytoplasm of the cells in this layer is densely packed with spherical uric acid granule. The finding of this study has shown that $\mathrm{P}$. tener have similar general histology structure of light organ of fireflies species that produce sharp flashes. However, the cylinder and trachea end cell may have significant capacities in controlling the luminescent creation in the fireflies that need to be investigate further.

Keywords: Bioluminescence; Coleoptera; insect histology; Lampyridae; light organ

\section{ABSTRAK}

Ultrastruktur organ cahaya kelip-kelip Pteroptyx tener ini dikaji dengan menggunakan mikroskop cahaya Axioscope dan mikroskop elektron penghantaran (TEM). Organ cahaya kelip-kelip jantan dan betina spesies ini terdiri daripada dua lapisan iaitu lapisan fotogenik dan lapisan dorsal yang juga dikenali sebagai lapisan pemantul. Lapisan fotogenik terdiri daripada beberapa unsur utama iaitu fotosit, zon pembeza, silinder, trakea dan sel hujung trakea. Fotosit adalah sel tempat proses bioluminesens berlaku. Sitoplasma sel ini padat dengan granul fotosit kecuali pada zon pembeza fotosit yang mempunyai bilangan mitokondria terbanyak berbanding pada bahagian sel yang lain. Lapisan pemantul terdiri daripada trakea dan sel yang dipenuhi dengan granul bulat asid urik. Kajian ini mendapati, struktur histologi umum organ cahaya P. tener mempunyai persamaan dengan struktur organ cahaya spesies kelip-kelip lain yang menghasilkan kelipan cahaya yang pantas dan teratur. Struktur silinder dan sel hujung trakea pada organ cahaya kelip-kelip mungkin mempunyai peranan penting dalam pengawalaturan penghasilan cahaya secara serentak dan kajian lanjut amat diperlukan.

Kata kunci: Bioluminesens; Coleoptera; histologi serangga; Lampyridae; organ cahaya

\section{INTRODUCTION}

Pteroptyx tener Olivier, 1907 (Coleoptera: Lampyridae) is a well-known tropical firefly species that exhibit synchronized flashings from its bioluminescent abdomen. In terms of their flashing behavior, there are two main types of congregating fireflies, the synchronous and the non-synchronous fireflies. Only a few firefly species in this world that could flash light synchronously and this include P.tener (Ballantyne \& Menayah 2000; Copeland \& Moiseff 1997; Jusoh et al. 2013; Morrison 1929; Smith 1935).

In Malaysia, this species can be found congregating near the mangrove tree such as Sonneratia caseolaris, Nypha fruticans, Rhizophora apiculata, Polyathia longifolia and Ficus sp. tree (Norela et al. 2017, 2016: Shahara et al. 2017). They flash synchronously for hours after sunset to attract their mating partner (Norela et al. 2017, 2016; Shahara et al. 2017). This species is among few species of fireflies that have 'perfect synchronization' (Case \& Hanson 2004; Fatimah \& Norela 2016). They produced sharp flash with average flashing duration of 320 milliseconds per flash (Fatimah \& Norela 2016). Differ from the males, females do not involve in synchronous flashing and the duration of the flash is longer, dimmer and irregular than the male (Buck 1988a, 1988b; Buck \& Buck 1978, 1968).

The luminous organ of both sexes is unique and evolved according to life stages. The organ varies in sizes from as small as pinhead to masses that occupy the entire ventral surface of the abdominal segments. The shape of the firefly organs also change from round to an entirely irregular shape extending from the head to the tip of the abdomen, including the thorax, both dorsal and ventral surfaces (Buck 1948; Buck \& Buck 1978). Light organ of $P$. tener male is located at the ventral of the sixth and seventh abdominal segment while the female only has one segment of light organ located at the sixth abdominal segment.

There are some earlier studies on the ultrastructure of the light organ, but mostly focusing on the American fireflies, Photinus and Photuris (Beams \& Anderson 
1955; Buck 1948; Hanson 1962; McDermott \& Crane 1911; Smith 1963). Limited work has been done on the luminescent structure of the Asian fireflies (Peterson $\&$ Buck 1968). Dearth of information on P. tener has encouraged us to explore and examine the ultrastructure of its light organ with the anticipation that the results of this study could contribute towards the understanding of the process of synchronous luminescent emission of this species particularly, and of other species in general.

\section{MATERIALS AND METHODS}

\section{SPECIMEN SAMPLING}

Adult of P. tener (Olivier 1907) were collected from the stretch of Sungai Selangor in Kampung Kuantan, Kuala Selangor located between $3^{\circ} 30^{\prime} \mathrm{U} ; 3^{\circ} 15^{\prime} \mathrm{U}$ latitude and $101^{\circ} 15^{\prime} \mathrm{T}$; $101^{\circ} 45^{\prime} \mathrm{T}$ longitude. The sampling period were done after sunset between 1900-2000 h from January to May 2014. Adult fireflies were captured alive using the sweep net and the live specimens were placed temporarily in air filled large plastic bags before being transferred to portable holding containers. Thirty specimens for each male and female were collected for light microscope observation and ten specimens for each male and female for ultrastructural studies.

\section{LIGHT MICROSCOPE}

Light organs (6th abdominal segment) of the adult fireflies were dissected and then preserved in $10 \%$ formalin overnight. The tissues were then dehydrated through a series of ethanol applications $(70 \%, 80 \%, 90 \%$ and $100 \%)$, followed by xylene. The tissues were then permeated with paraffin wax and embedded. Blocks of waxed tissues were sectioned by a LEICA RM2245 microtome and set to cut at $4 \mu \mathrm{m}$. Four to five sections were placed on a slide and dried overnight. Sectioned tissues were then stained with Hematoxylin and Eosin reagent method (AFIP 1968). Slides were mounted with DPX mounting medium. Microphotography was taken by Carl Zeiss Axio Scope A1 photomicroscope with iSolutionLite v1.0 software for observation.

\section{TRANSMISSION ELECTRON MICROSCOPE}

The isolated light organs of $P$. tener were preserved in a $2.5 \%$ glutaraldehyde diluted in phosphate buffer saline (PBS) for $24 \mathrm{~h}$ at $4^{\circ} \mathrm{C}$. They were then washed with $0.1 \mathrm{M}$ PBS three times for the duration of $10 \mathrm{~min}$ each. Next, the specimens were immersed in $1 \%$ Osmium Tetroxide (OsO4) for secondary preservation for $2 \mathrm{~h}$, and then washed with PBS three times for $10 \mathrm{~min}$ each. Serial dehydration was carried out with ethanol concentration increased from $35 \%, 50 \%, 75 \%$, and $9 \%$ to $100 \%$ for 30 min each step at room temperature. Dehydrated specimens were washed in $100 \%$ ethanol twice for 30 min each step. After dehydration, the slide samples were permeated with acetone and resin mixture before being placed in beam capsules for embedded with resin. The specimens were polymerized in an oven at $60^{\circ} \mathrm{C}$ for $48 \mathrm{~h}$. Ultrathin sections of $90 \mathrm{~nm}$ thickness were obtained using an ultra-microtome and the sections were stained with uranyl acetate (Smith 1968). TEM image were obtained using a transmission electron microscopy (120kV FEI Tecnai BioTWIN) and an image analyzing computer.

\section{RESULTS AND DISCUSSION}

This species has shown similar general structure of other firefly light organ from previous studies that consist of two defined layers, i.e. dorsal layer and the photogenic layer (Figure 1) (Beams \& Anderson 1955; Buck 1948; Hanson 1962; McDermott \& Crane 1911; Oertel et al. 1975; Smith 1963). Although the female firefly does not involve in synchronous luminescent production, our results indicate that there are similarities in the general structure of the light organs of both male and female (Figure 1). Buck (1948) had described that there were six types of light organ arrangement and $P$. tener light organ structure fits the description of Type 6 firefly light organ arrangement that is commonly found in American fireflies, Photinus and Photuris. The different of structure in Type 6 light organ that has special structure is known as cylinder. This structure (cylinder) will be discussed and elaborated further under a separate topic of photogenic layer.
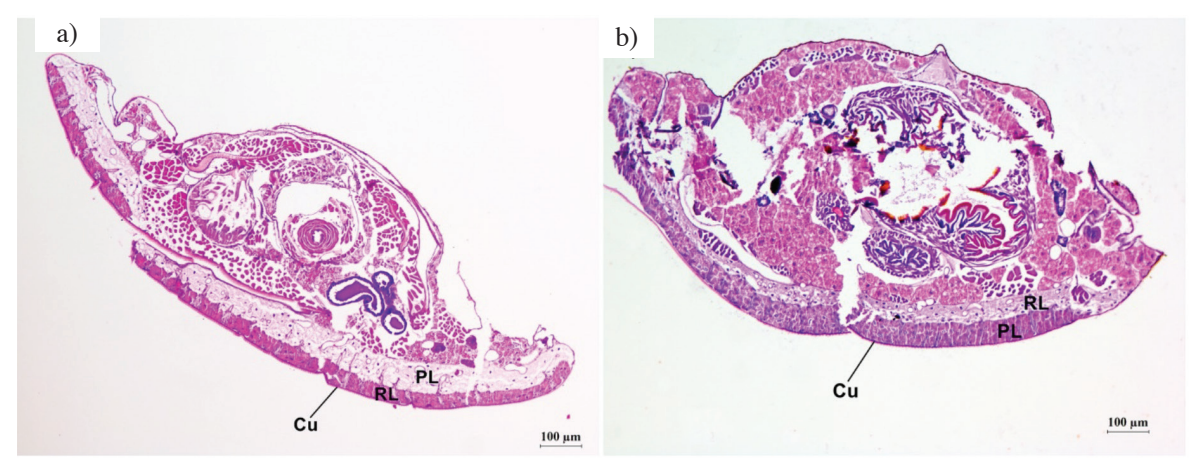

FIGURE 1 . Cross section of the $6^{\text {th }}$ abdominal segment of a) male and b) female. (10×). $\mathrm{Cu}$, cuticle; PL, photogenic layer; RL, reflector layer 


\section{DORSAL LAYER}

The dorsal layer, also known as the reflector layer is white and opaque. It also covers the dorsal photogenic layer (Figure 1). This layer is three cells thick and the cell cytoplasm is packed with tiny spherical granules (Figure 2). TEM observations indicate that these granules are spherical and similar in size (Figure 3). A high number of tracheas is also seen in this layer (Figure 2).

In contrast to the photogenic layer, acidic dye eosin has failed to stain the cells in this layer. This suggests that this layer has different chemical constituents and the structure is also very different from that of the photogenic layer. This layer is believed to function as a reflector for the luminescent produced in the photogenic layer. This was proven to be true by studies done by Goh et al. (2013) that showed this layer was capable of reflecting bioluminescence and increased the light intensity. They also believed that the densely packed tiny granules of uric acid in this layer had allowed the tissues to act as a physical barrier for bioluminescence activity. The cells in this layer are considered acidic resulting from eosin failed to stain the cell cytoplasm. According to Goh et al. (2013), the granules were uric acid granules and insect uric acid can produce a white pigment. This might explain why the dorsal layer has white and opaque color in living tissues.

\section{PHOTOGENIC LAYER}

The photogenic layer is located between the cuticle and the dorsal layer (Figure 1). This layer separated from the dorsal layer by an acellular tunic or cell membrane (Figures 4 \& 5). Photogenic layer is two cells thick and is usually thinner than the reflector layer. The living photogenic layer is transparent in color. This layer is composed of several distinct elements i.e. the photocyte cells, cylinder, trachea and end cells (Figures $4 \& 5$ ).

The photocyte cell is in cuboidal shape with $22 \mu \mathrm{m}$ $35 \mu \mathrm{m}$ in diameter. A horizontal section through this layer shows a 'rosette' arrangement of photogenic cells around the trachea (Figures 4(b) \& 5(b)). Observations of the fine structure of this cell showed that the cytoplasm of this cell was composed of photogenic granules (PG) (Figures 4, 5, 6(a) \& 6(b)). The chemical reaction of luminescent production may occur in these granules. Previous studies done on this species showed that enzyme luciferase is localized in the PG (Nur Khairunnisa et al. 2016).

There is a reduction in the number of PG that can be seen at the periphery of the cell cytoplasm adjacent to the tracheal cylinder and this area is known as the differentiated zone (DZ) (Figures 4 \& 5) (Buck 1948). The zone might differ chemically from the rest of the cytoplasm, as indicated by its different response to the eosin dye. The layer of differentiated photogenic cell cytoplasm is

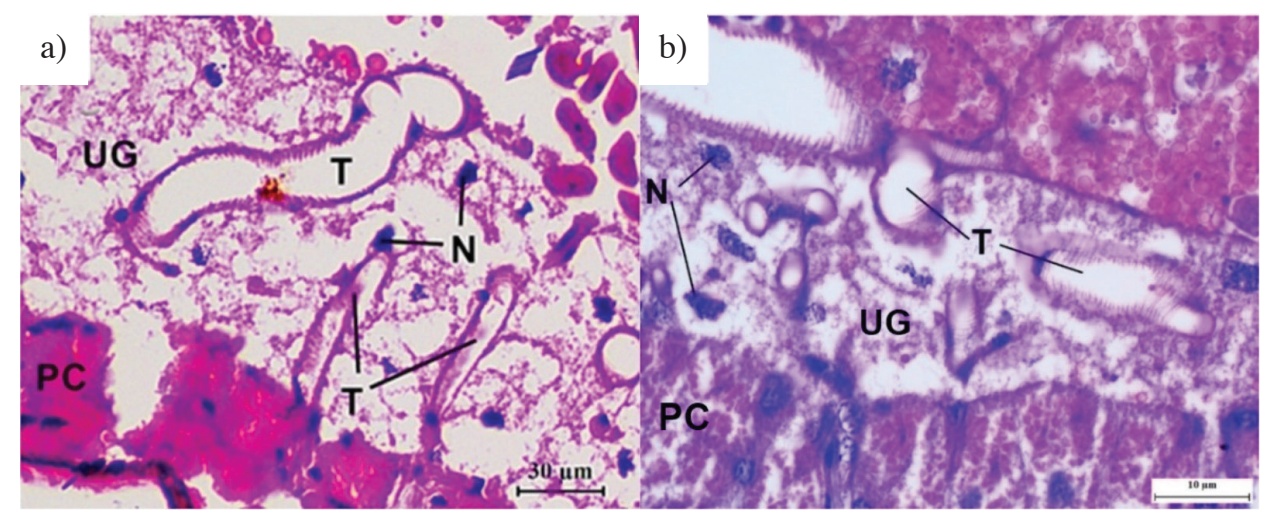

FIGURE 2. Transverse section of the reflector layer. a) Male light organ \& b) Female light organ $(100 \times) \mathrm{N}$, nucleus; PC, photocyte; T, trachea; UG, acid uric granule

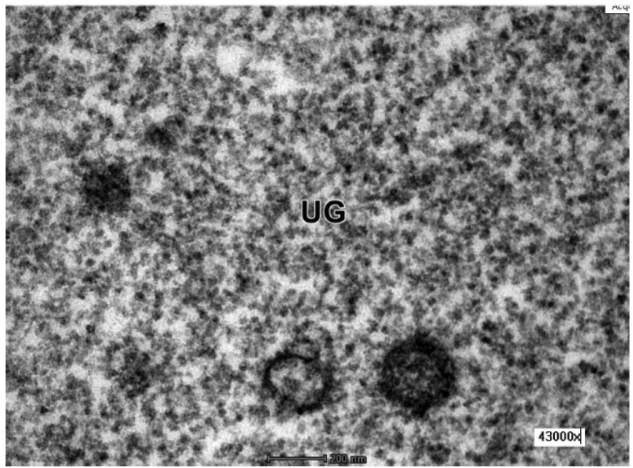

FIGURE 3. TEM image of reflector layer. UG, urate granule 

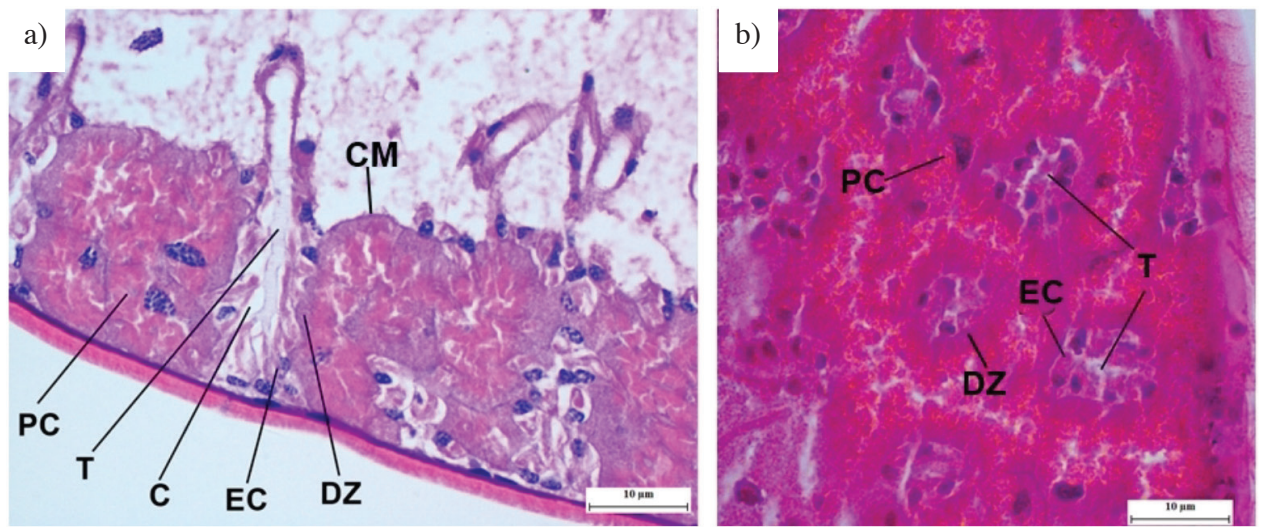

FIGURE 4. Sections of P. tener male light organ, a) Transverse section of the light organ (40x); b) Horizontal section showed 'rosettes' arrangement of the photogenic cells around the trachea $(100 \times)$. C, cylinder; CM, cell membrane; $\mathrm{DZ}$, differentiated zone; EC, end cell; PC, photocyte; T, trachea
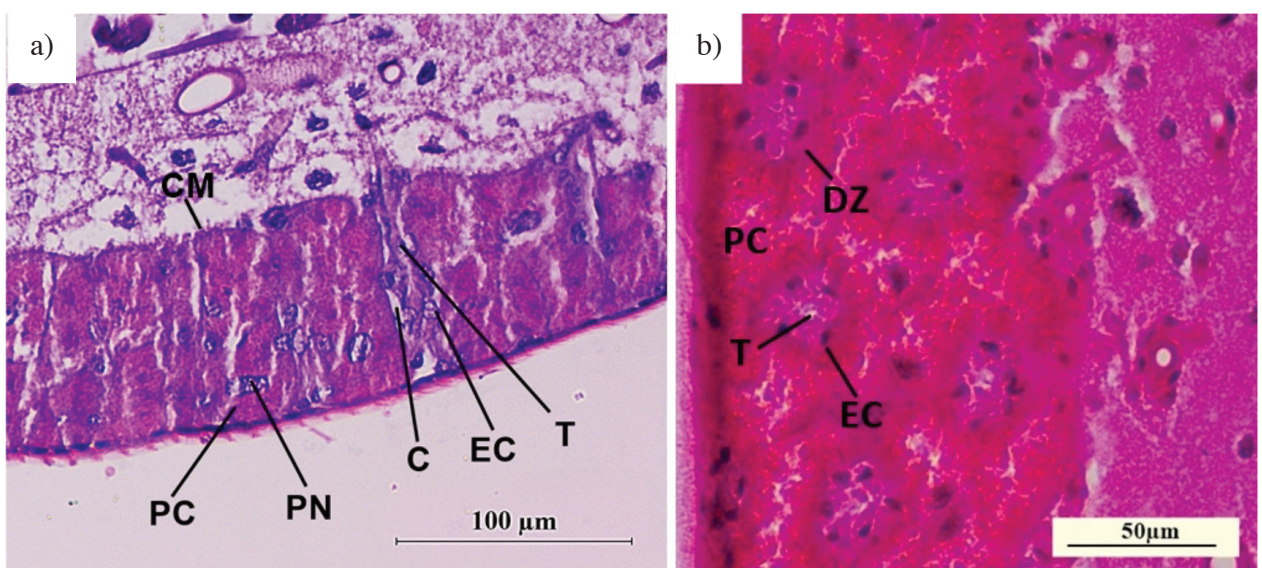

FIGURE 5. Sections of $P$. tener female light organ, a) Transverse section of the light organ (40x); b) Horizontal section showed 'rosettes' arrangement of the photogenic cells around the trachea (100x).C, cylinder; CM, cell membrane; DZ, differentiated zone; EC, end cell; PC, photocyte; PN, photocyte nucleus; T, trachea

relatively reflective to hematoxylin staining. Observation with TEM shows that this zone is packed with mitochondria and is lacking of photocyte granules (Figure 6(c) \& 6(d)). The presence of large number of mitochondria in this area that is adjacent to the trachea end cell may indicate the luminescent production site of ATP (Smith 1963).

A large number of tracheas could be observed on the internal surface of the reflector layer (Figure 3 ) and the photogenic layer (Figures 2, 4 \& 5). The tracheal branches are seen extending down through both layers to its ventral surface (Figures 2, 4(a) \& 5(a)). The main transverse tracheal trunks could also be observed to be greatly enlarged in the region of the light organ (Figure 2(b)). This rich supply of trachea is presumably necessary to supply oxygen to the photogenic cell containing the luciferin and enzyme luciferase as the tracheole is seen to have penetrated the cell. Therefore, it is most likely that the chemical reaction for synchronously flashing light needs a lot of oxygen supply.

The tracheal trunks in the photogenic layer do not pass the photogenic cell directly but through cylindrical rods of tissue to its ventral surface and this special structure known as cylinder (Figures 4 \& 5). Buck (1948) assumed that this structure maybe filled with gelatinous matrix. This structure is a tunnel-like region that is surrounded by the differentiated zones of the photogenic cells. Each cylinder is surrounded by a radial rosette of photogenic cells (Figures 4(b) \& 5(b)). Within the cylinder, the tracheal trunk branched laterally to numerous branches of short tracheal twig (Figure 4(a)). The tracheal twig then divided into tracheole within the end cell (Figure $7(\mathrm{c}))$. The end cell is specialized cell presence at the end of the light organ tracheal twig (Figures $4 \& 5$ ). Figure 7 (a) and 7(b) shows that the end cell cytoplasm is filled with mitochondria and wrapped around the tracheole. Previous studies showed cylinder and end cell can only be found in the light organ of fireflies that produce the sharp flashes of light (Beams \& Anderson 1955; Buck 1948; Peterson \& Buck 1968).

Section of end cell indicate that the tracheal twig divided into two tracheoles. Apparently, number of tracheoles originated from one tracheal twig is always 

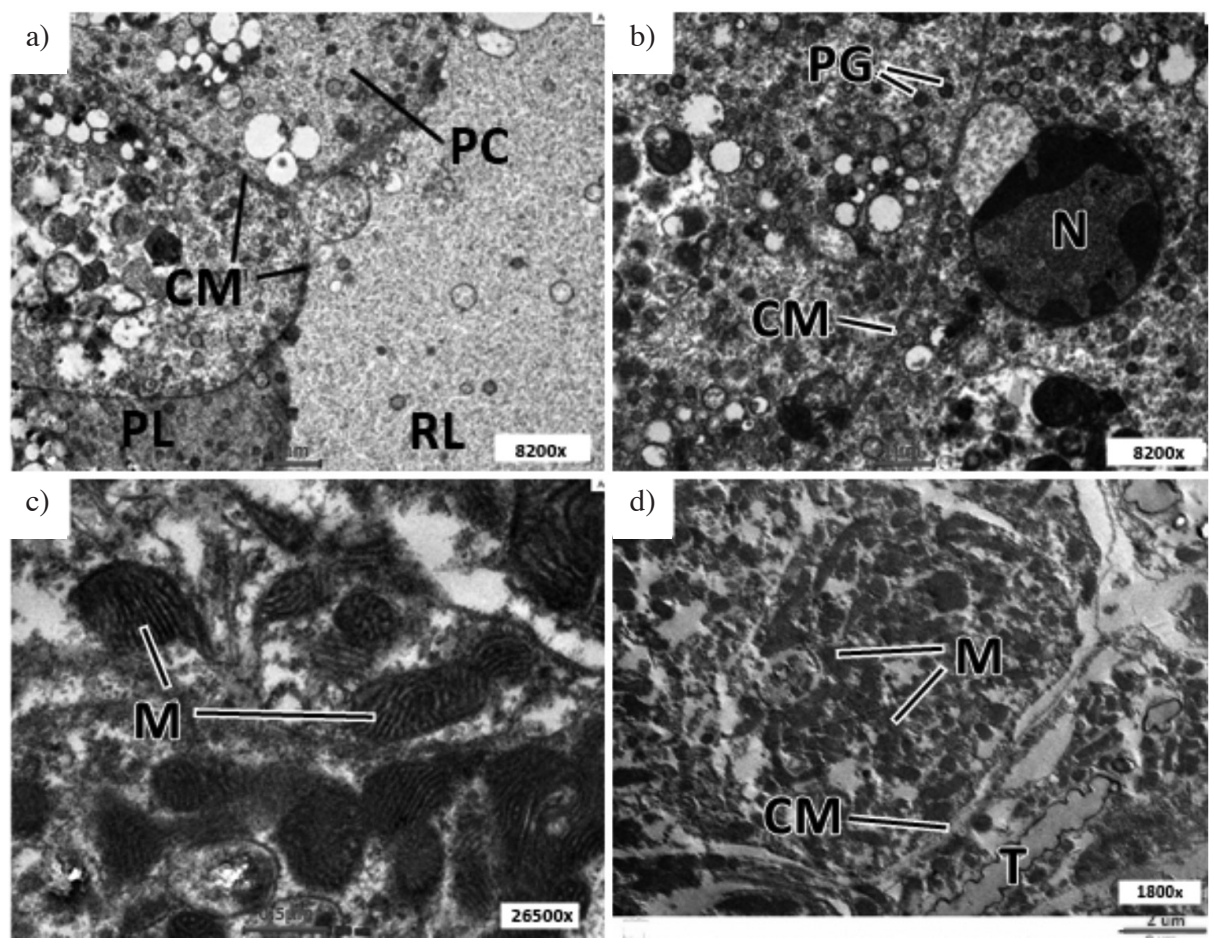

FIGURE 6. TEM image of P. tener light organ, a) Cross section part of the border between the reflector layer and the photogenic layer; b) Sections of the photocyte; c) Transverse section of male differentiated zone d) Transverse section of the female differentiated zone showing mitochondria concentrated adjacent to the trachea. $\mathrm{CM}$, cell membrane; M, mitochondria; $\mathrm{N}$, nucleus; PC, photocyte; PG, photocyte granule; PL, photogenic layer; RL, reflector layer; T, trachea
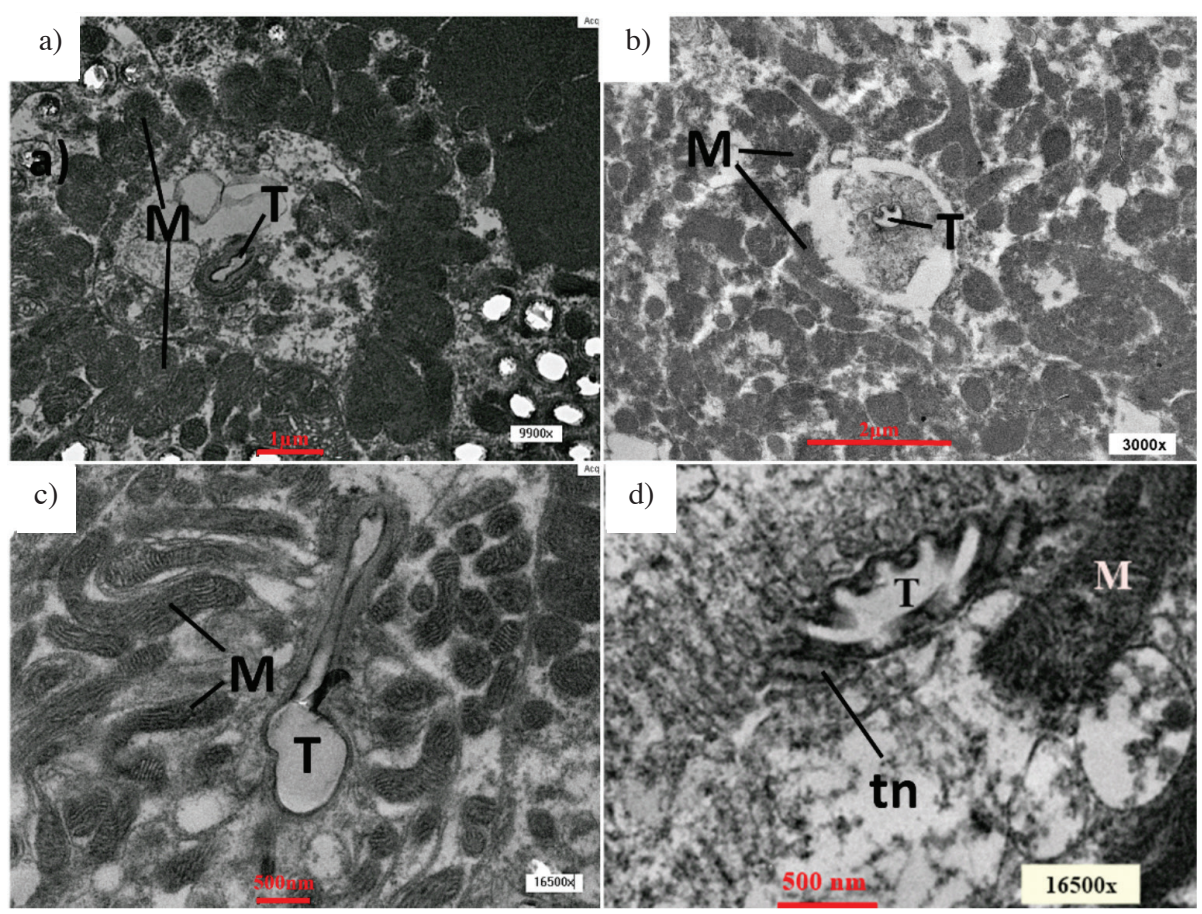

FIGURE 7. TEM image of $P$. tener light organ. Section of a) male and b) female tracheal end cell, c) Tranverse section of end cell showed trachea twig branched to two tracheole; and d) Longitudinal section of tracheole showed the taenidial fold around the tracheole wall. M, mitochondria; $\mathrm{T}$, trachea; $\mathrm{tn}$, taenidia

two for Asian fireflies, in contrast to the two or three for Photuris and three or four for Photinus (Peterson 1980). Both trachea and tracheole of the $P$. tener light organ have taenidial fold (Figures $2 \& 7(d)$ ). Taenidia is the spiral thickening of the trachea and tracheole cuticle. The presence of the taenidia is to reinforce the trachea and 
tracheole structure and make it resistant to collapse or bending (Ghiradella 1978, 1977). Studied by Ghiradella (1978), showed there are distinct differences in tracheoles from different tissues, but the lampyrid light organ always have reinforced tracheole especially the flashing fireflies. This indicated that the light organ function required stiffened tracheal system.

\section{CONCLUSION}

The finding of this study shows the similarities in the general structure of the light organ among the various species of fireflies that comprised of the reflector layer and the photogenic layer. In addition to that, although male and female of $P$. tener have different size and flash pattern behavior, general cytological structure of both light organs are similar. The photogenic layer of P. tener also consist of the cytological structure of all firefly species that produce sharp flashes of bioluminescent that consists of photocytes with a differentiated zone, a tracheal end cell and a cylinder. This may support that these elements may have significant function in controlling the light production in firefly's light organ.

\section{ACKNOWLEDGEMENTS}

The authors would like to thank Prof. Dr. Maimon Abdullah for her kind editing and critical comments of this paper. This study was funded by grants ST-2017-013, LAUREATE-2013-02, and GUP-2014-086.

\section{REFERENCES}

Armed Forces Institute of Pathology (AFIP). 1968. Manual of Histologic Staining Methods. New York: McGraw-Hill.

Ballantyne, L.A. \& Menayah, R. 2000. Redescription of the synchronous firefly, Pteroptyx tener Olivier (Coleoptera: Lampyridae), of Kampung Kuantan, Selangor. Malayan Nature Journal 54(4): 323-328.

Beams, H.W. \& Anderson, E. 1955.Light and electron microscope studies on the light organ of the firefly (Photinus pyralis). The Biological Bulletin 109(3): 375-393.

Buck, J.B. 1988a. Synchronous rhythmic flashing of fireflies. The Quarterly Review of Biology 13(3): 301-314.

Buck, J.B. 1988b. Synchronous rhythmic flashing of fireflies. II. Quarterly Review of Biology 13(3): 265-289.

Buck, J.B. 1948. The anatomy and physiology of the light organ in fireflies. Annals of the New York Academy of Sciences 49(3): 397-485.

Buck, J. \& Buck, E. 1978. Toward a functional interpretation of synchronous flashing by fireflies. The American Naturalist 112(985): 471-492.

Buck, J. \& Buck, E. 1968. Mechanism of rhythmic synchronous flashing of fireflies of Southeast Asia may use anticipatory time-measuring in synchronizing their flashing. Science 159(3821): 1319-1327.

Case, J.F. \& Hanson, F.E. 2004. The luminous world of John and Elisabeth Buck. Integrative and Comparative Biology 44(3): 197-202.
Copeland, J. \& Moiseff, A. 1997. The effect of flash duration and flash shape on entrainment in Pteroptyx malaccae, a synchronic Southeast Asian firefly. Journal of Insect Physiology 43(10): 965-971.

Fatimah Abdul Razak \& Norela Sulaiman. 2016. Synchronization of Malaysian fireflies: The case of Pteroptyx tener at Kampung Kuantan, Selangor, Malaysia. The Malayan Nature Journal 68: 223-228.

Ghiradella,H. 1977. Fine structure of the tracheoles of the lantern of a Photurid firefly. Journal of Morphology 153(2): 187-203.

Ghiradella, H. 1978. Reinforced tracheoles in three firefly lanterns: Further reflections on specialized tracheoles. Journal of Morphology 157(3): 281-299.

Goh, K.S., Sheu, H.S., Hua, T.E., Kang, M.H. \& Li, C.W. 2013. Uric acid spherulites in the reflector layer of firefly light organ. PLoS ONE 8(2): e56406.

Hanson Jr., F.E. 1962. Observation on the gross innervation of the firefly light organ. Journal of Insect Physiology 8(1): 105-111.

Jusoh, W.F.A., Hashim, N.R. \& Adam, N.A. 2013. Distribution of the synchronous flashing beetle, Pteroptyx tener Olivier (Coleoptera: Lampyridae), in Malaysia. The Coleopterists Bulletin 67(4): 604-605.

Morrison, T.F. 1929. Observations on the synchronous flashing of fireflies in Siam. Science 69(1789): 400-401.

Norela Sulaiman, Loo, M.C. \& Maimon Abdullah. 2017. Association between the firefly population and some biotic and abiotic factors along the Sungai Sepetang River banks at Kampung Dew, Taiping, Perak, Malaysia. The Malayan Nature Journal 69(3): 159-167.

Norela, S., Shahril, M.H., Mohd Noh, A.N., Maimon, A. \& Nur Khairunnisa, S. 2016. Abundance of Lampyridae in relation to the vegetation and abiotic conditions along the Sungai Johor, Johor, Malaysia. Malayan Nature Journal 67(4): 395-402.

Nur Khairunnisa, S., Nurul Wahida, O. \& Norela, S. 2016. The localization of luciferase in Pteroptyx tener (Coleoptera: Lampyridae) light organ. Serangga 21(1): 55-62.

Oertel, D., Linberg, K. \& Case, J. 1975. Ultrastructure of the larval firefly light organ as related to control of light emission. Cell and Tissue Research 164(1): 27-44.

Peterson, M.K. \& Buck, J. 1968. Light organ fine structure in certain Asiatic fireflies. Biological Bulletin 135(2): 335-348.

Shahara, A., Nura, A.M.R., Maimon, A. \& Norela, S. 2017. Assessment of firefly abundance at a new ecotourism site of Sungai Bernam, Selangor, Malaysia. The Malayan Nature Journal 69(2): 67-74.

Smith, D.S. 1968. Insect Cells: Their Structure and Function. First ed. Edinburgh: Oliver and Boyd.

Smith, D.S. 1963. The organization and innervation of the luminescent organ in a firefly, Photuris pennsylvanica (Coleoptera). The Journal of Cell Biology 16(2): 323-359.

Smith, H.M. 1935. Synchronous flashing of fireflies. Science 82(2120): 151-152.

Nur Khairunnisa binti Salleh, Nurul Wahida binti Othman \& Norela binti Sulaiman*

Center of Insect Systematics

School of Environmental and Natural Resource Sciences

Faculty of Science and Technology

Universiti Kebangsaan Malaysia

43600 UKM Bangi, Selangor Darul Ehsan

Malaysia 
Nur Khairunnisa binti Salleh, Nurul Wahida binti Othman, Norela binti Sulaiman* \& Ismail bin Sahid

School of Environmental and Natural Resource Sciences Faculty of Science and Technology

Universiti Kebangsaan Malaysia

43600 UKM Bangi, Selangor Darul Ehsan

Malaysia

Norela binti Sulaiman*

Fraser`s Hill Research Centre

Faculty Science and Technology

Universiti Kebangsaan Malaysia

43600 Bangi, Selangor Darul Ehsan

Malaysia
*Corresponding author; email: vozela@ukm.edu.my

Received: 4 September 2018

Accepted: 8 February 2019 